University of St. Thomas, Minnesota

UST Research Online

$9-24-2012$

\title{
Will The America Invents Act Post-Grant Review Improve The Quality Of Patents? A Comparison with the European Patent Office Opposition
}

Susan J. Marsnik

University of St.Thomas, Minnesota, sjmarsnik@stthomas.edu

Follow this and additional works at: https://ir.stthomas.edu/ocbeblpub

Part of the Business Law, Public Responsibility, and Ethics Commons

This Book Chapter is brought to you for free and open access by the Ethics and Business Law at UST Research Online. It has been accepted for inclusion in Ethics and Business Law Faculty Publications by an authorized administrator of UST Research Online. For more information, please contact asle4660@stthomas.edu. 


\section{Will The America Invents Act Post-Grant Review Improve The Quality Of Patents? A Comparison with the European Patent Office Opposition}

\section{Susan J. Marsnik*}

After years of attempts to reform its sixty-year-old patent law, in September of 2011 the United States enacted The Leahy-Smith America Invents Act (AIA). The law ushers in substantial changes in U.S. patent law and practice. Significant among the changes are a number of new trial proceedings though which third parties may challenge patents at U.S. Patent and Trademark Office (PTO) once the patent has issued. The AIA law introduced three new or revised post issuance inter partes proceedings: post-grant review, inter partes review, and a specialized post-grant review for certain business methods. These proceedings address rising concerns over a perceived proliferation of poor quality patents due to substantial increases in the number of patent applications in the U.S. The primary avenue for testing the validity of patents

in the U.S. has been litigation, which is both costly and time consuming. A primary justification for the new post issuance proceedings was to provide a faster and less expensive alternative to litigation. Providing an opportunity for third parties to intervene post issuance is not new in the U.S. system. Since 1981, third parties or the patent owner have been able to request an examination of an already issued patent through an ex parte reexamination. In 1999, the American Inventors Protection Act introduced an administrative inter partes reexamination, which was not been widely used. The AIA replaces inter partes reexamination with the inter 
partes review. This chapter focuses primarily on post-grant review, the most powerful and broadest of the new post issuance proceedings.

Post issuance review systems have long been debated in U.S. academic, legal and business circles as a way to reduce the incidence of invalid or poor quality patents in a more cost efficient manner. It was natural to turn to the European system as part of the discussion. For almost four decades, the European Patent Office (EPO) has heard and decided post grant oppositions under the European Patent Convention (Convention on the Grant of European Patents (EPC), 2010). Empirical studies demonstrate that the more valuable or technologically important a patent, the more likely it will trigger an opposition in the EPO, just as it is more likely to be litigated in the U.S. The opposition system has been successful in correcting EPO examination errors through invalidating or narrowing patents. The success of the European opposition system has served as a justification for post-grant review in the U.S. Proponents have argued that allowing a patentee's competitors to intervene post issuance at the PTO will improve the quality of patents granted since competitors often have access to critical art not available to the examiners. Society as a whole will also benefit from reducing the number of invalid patents earlier and without the costs and delays of patent litigation.

The AIA incorporates certain features of the European opposition into the post-grant review. However, substantial differences exist which makes post-grant review in the U.S. a less effective tool for improving the quality of patents. This chapter begins with part one discussing the rationale for the new post-grant review and shortcomings under the pre-AIA system, including utilizing the litigation system as the primary vehicle for invalidating patents after grant. Part two considers the post grant opposition system operating in Europe followed by a 
description of the new AIA post grant review system in part three. Part four analyzes whether the new American system will fulfill the rationale of a more cost efficient, faster means of ensuring patent quality in the United States. The author concludes that the costs associated with postgrant review and its potent estoppel rules make it unlikely tool for improving the quality of patents or stemming the tide of patent litigation in the U.S.

\section{Rationale for Post Issuance Review}

The traditional utilitarian justification for patents is providing incentives to invent benefits both society and inventors. In the U.S., the quid pro quo of the patent systems requires complete disclosure of the invention in exchange for powerful rights granted to the patentee to exclude others from making, using, and selling the patented invention. The public benefits. Full disclosure facilitates further innovation and invention based on the patent and the patented invention enters the public domain in twenty years. The patent owner benefits from the ability exploit the patent. Patents that are invalid or too broad place an unwarranted burden on innovation and society. Uncertainty about the validity of a patent can deter investment and impact the direction of innovation (Farrell and Merges, 2004). Bad quality patents can encourage infringement lawsuits and settlements, which raise transaction costs that are passed on to consumers (Merrill, Levin and Myers, 2004). Therefore, invalid patents can have a powerful negative impact and society benefits by eliminating them.

Concerns over declining patent quality has been linked to a dramatic increase in the number of patent applications filed with and granted by the PTO. In 1980, 104,329 utility patent applications were filed. The number almost quintupled to 503,582 in 2011. During the same 
period, the number of utility patents granted increased from 61,819 to 224,505 (PTO Patent Statistics Report, 2012). A number of factors contribute to the dramatic expansion in applications. In part, it results from an increased interest in acquiring, using and enforcing patents domestically as well as by foreign applicants who wish to exploit their inventions in the U.S. Courts in the U.S. have also expanded patentable subject matter to include those related to biotechnology, computer software and business methods. Patents have grown increasingly complex in terms of the number of claims and references to prior art, making examination a more arduous task. All of these factors contribute to an examination backlog. The PTO reported more than 1.2 million pending utility patent applications in its most recent Performance and Accountability Report (PTO, 2011). The sheer number of patent applications, the substantial backlog, and increased productivity pressures at the PTO pose serious threats to the quality of patents issued. (Thambisetty, 2007; Hall and Harhoff, 2004). Improving the quality of examination so that fewer questionable patents are granted could provide a solution to the patent quality conundrum. However, this would not be desirable as most patents are not valuable. It makes more sense to focus resources on patents likely to have the greatest societal impact in terms of both innovation and competitors.

In the U.S., litigation provides the primary avenue for contesting 'bad' patents. Not all questionable patents are challenged in court. Litigation focuses on the most important technologically and commercially viable patents (Allison, Lemley and Walker, 2009; Allison, Lemley, Moore and Tunkey, 2004; Graham \& Harhoff, 2006). Litigation is a costly vehicle to test patents. The American Intellectual Property Law Association Law Practice Management Committee reported the median costs of patent litigation with between one and twenty-five 
million dollars at risk at $\$ 1.5$ million through the end of discovery and $\$ 2.5$ million inclusive of all costs (AIPLA, 2011). Not only is it costly, asymmetries existing in the litigation system impact results. Farrell and Merges explain that patentees have much greater incentives to pursue infringement lawsuits or defend vigorously on the issue of patent validity than putative infringers have to bring an action (2004). The press and academic literature are filled with reports on nonpracticing entities, often characterized as trolls, filing infringement lawsuits against numerous small competitors and then settling for a licensing fee. The alleged infringers have little economic incentive to challenge the validity of a patent in court. Litigating and losing may be far worse than paying the patent owner's demand for a license, even though the alleged infringer may not believe the patent is valid. Challenging validity in court could bankrupt a small company or lead to an injunction that could shut down its business. Furthermore, if the court upholds the patent, the patentee may refuse to license essential technology the infringer needs to operate. A better business alternative for a competitor might be to avoid the lawsuit completely or settle the lawsuit by accepting a license from an owner of a questionable patent. The costs can be passed on to the consumer. The pass through of costs related to questionable patents illustrates the public's stake in lawsuits challenging patents in a way that does not exist in other economic lawsuits (Farrell and Merges, 2004). The ability to settle litigation runs counter to society's interest in ensuring patents are valid. When a lawsuit related to a questionable patent is settled, society may never know whether that patent really was valid. This can hamper innovation and investment.

For years, scholars, practitioners and government bodies have advocated instituting post issuance administrative trial proceedings at the PTO to determine validity more efficiently than litigation. (Matal, 2012; Carrier, 2011; Carlson and Migliorina, 2006; Farrell and Merges, 2004; 
Merrill, et al., 2004; Federal Trade Commission, 2003; McKie and Edward, 1974). Because of the European Patent Office's history with post grant oppositions, a procedure imbedded in the EPC in 1973, many have turned to that model as a rationale for instituting post-grant review in the U.S. Empirical studies demonstrated the efficiencies of oppositions, particularly since the most valuable patents granted by the EPO are opposed (Caviggioli, Scellato, and Ughetto, 2012; Hall and Harhoff, 2004; Graham, Hall and Harhoff, 2002). The value of patents determines whether those patents are opposed in the EPO, just as the most valuable patents are litigated in the U.S. A number of factors indicate whether a patent will be opposed. Patents will be attacked more frequently if they contain a higher number of backward citations to previous patents. Scellato et al. posit that the positive correlation between a higher incidence of oppositions and a larger number of previous patent citations may indicate a more questionable inventive step: that the patent doesn't meet non-obviousness criteria (2011). The owners of the cited patent may more readily become aware of the newly granted patent so can make a decision about filing an opposition more quickly than another third party. Forward citations in subsequent patents are also relevant to value. Greater numbers of citations in subsequent inventions indicate the patent contributes to the state of the art (Scellato et al., 2011). The number of claims, which can indicate the relative complexity of the patent, is also positively and significantly correlated with the likelihood of opposition (Caviggioli et al, 2012).

Currently, approximately 5\% of all granted European patents are opposed (Boff, 2011; Caviggioli et al., 2012). This indicates a downward trend from a norm of $9.25 \%$ between 1980 and 2000. Scellato, et al. suggest the decrease might have resulted from improvements in EPO examination or greater number of marginal patents not opposed (2011). However, given the significant increase in patent applications to the EPO during the same period the PTO has 
experienced increases, it is probable the more valuable patents opposed may represent a smaller percentage of the total number of patents granted by the EPO. There may also exist a free rider problem. If a patent of questionable quality negatively impacts multiple competitors, individual firms may wait for someone else to bear the cost of opposition (Scellato, et al., 2011).

Oppositions correct a significant number of examination mistakes. Roughly one third of oppositions are rejected with the patents remaining intact as granted. Approximately one third are revoked in their entirety and one third are maintained in amended form that narrow their breadth (Boff, 2011; Hall \& Harhoff 2004). Oppositions serve a positive screening function of weeding out a substantial number of bad patents and narrowing a substantial number that are too broad. This positive screening function led to advocacy on this side of the Atlantic to include a strong post-grant review mechanism in the U.S. patent system. Indeed, the stated purpose of the post-grant review procedure in the AIA is to "establish a more efficient and streamlined patent system that will improve patent quality and limit unnecessary litigation costs."(PTO, Rules of Practice, 2012).

\section{European Patent System}

The EPO houses the largest and most successful system of post issuance inter partes review. The contours of the European opposition provide a good background against which to measure the new procedures in the AIA. The legal landscape for protecting patents within Europe is substantially different from that in the U.S. Rather than a unitary patent application and enforcement system that covers the entire territory, Europe has a dual system of multinational and national patent law. What we call a "European" patent is not a single patent 
covering all of Europe. ${ }^{1}$ It is a set of independent national patents created under the EPC using a single application through the EPO where it is examined. A person wishing to patent an invention in an EPC contracting state may either file a national application in the patent office in each country in which protection is sought, or file one application with the EPO in Munich designating all of the contracting states in which they desire protection. Because all contracting states have transposed the EPC into national law, the law should be harmonized such that if a person takes the national route a patent is granted in Germany should also be granted in France and the U.K. However, this is not always the case as European nations do not all approach patenting in the same manner. It is possible for one national office to grant a patent and another to deny it. National offices subject patent applications to different examination procedures, interpretations of the law and requirements and formats for claims. Even if the patent is granted by more than one national office, a patent for the same invention may differ in both form and scope from one country to another (Hoyng, 2006). The resulting lack of consistency makes the single EPO application process a more attractive avenue. If the EPO grants the European patent, it begins its life with the same form and scope in each European country.

The European patent does not immediately become a German or Italian patent. The owner must validate or "nationalize" the patent in each of the countries it has designated. The European patent becomes a bundle of national patents governed by national patent law and enforced in that country (EPC Art. 64(1); Rudge, 2012). Once validated in a contracting state, the patent is entirely independent of the validated patent in every other contracting state. Enforcement and revocation become entirely matters of national law. Because of differences in national law and differing legal traditions, it is possible for a patent granted by the EPO to be revoked in one contracting state, but not another (Marsnik \& Thomas, 2011). The primary 
exception to national sovereignty over a European patent once it has been granted and validated is the post grant opposition procedure within the $\mathrm{EPO}^{2}$. A number of factors make a third party challenge to validity through an opposition more attractive than bringing a revocation proceeding in each country. A primary advantage is consistency. If the EPO determines a patent should not have been granted or narrows the scope of the claims, that decision has immediate application in all of the EPC contracting states in which the patent had been validated. If a party is seeking patent protection in a number of European nations, the EPO application and opposition system is more efficient than the national route, both in terms of cost and uniformity.

\section{A. The EPO Opposition and Appeal}

Any third party, except the proprietor of the patent, who believes that the patent should not have been granted may file an opposition (EPC, 2010, Art. 99). The third party need not have an interest. It is possible for a third party to keep his identity secret from the patent owner by using a "straw man" to file the opposition on his behalf. (Case G 9/93,1994). The opposition must be filed within nine months of the grant of the patent (EPC, 2010, Art. 99). If a challenger misses the nine month window, the only way to challenge the validly of the patent is through a patent revocation procedure under the national laws of the countries in which the patent is validated. Article 100 lists the broad grounds upon which oppositions may be based including the "invention" does not meeting patentability criteria, was not sufficiently disclosed or the subject matter extends beyond the original application (EPC, 2010). The EPO's Opposition Division examines the notice to ensure that the opposition is admissible, that it meets the formal 
requirements for opposition (EPO 2012, Part D). If so, it proceeds to a panel of three experienced technical examiners, one of whom may have been involved in the original examination. If particular legal expertise is required, a legally qualified examiner may be added. The opposition is not a reexamination. It is an inter partes proceeding in which the Opposition Division acts in a quasi-judicial role. However, unlike a court, the Opposition Division is not required to limit its determination to the grounds invoked by the parties. On its own motion, the Opposition Division may consider other grounds for opposition (EPC, 2010, Rule 8).

There are four possible outcomes to an opposition: (1) the opposition may be rejected; (2) the patent may be fully revoked as invalid; (3) the patent may be maintained, but in an amended form narrows the patent by modifying its claims; or (4) the opposition may be closed without an outcome, typically because the opposition is withdrawn or the patent has lapsed for failure to pay maintenance fees in all EPC member states in which it has been filed. Narrowing the scope of the patent often takes the form of a negotiation between the parties with the Oppositions Division panel serving as mediator (Graham and Harhoff, 2006). Although settlement is possible, once an opposition has been filed, parties' opportunities are restricted. Rule 84(2) of the Implementing Regulations allow the EPO to proceed with the opposition on its own motion after the parties have withdrawn (EPC, 2010). If the Opposition Division has reasonable grounds to believe that a limitation or revocation is likely, it will proceed despite the absence of the parties. This serves as a powerful deterrent against settlement, since the EPO may modify or invalidate the patent without regard to the parties' settlement agreement and without their input. It also discourages using the opposition strategically to harass a patent holder. (Graham and Harhoff, 2006). Only a small number of opposition cases close without reaching 
an outcome. Hall and Harhoff reported the number closing without outcome to be 5.3\% and most likely capture incidences in which the parties have settled (2004).

Either party or both may appeal the decision of the Opposition Division to the EPO Technical Boards of Appeal (the Board). There are twenty-seven Boards, each highly specialized in a particular subject matter expertise. The particular Board hearing an opposition appeal interprets and applies the EPC and case law. One third of oppositions are appealed (Hall and Harhoff, 2004). Filing the appeal prevents the Opposition Division's decision from entering into force until the appeal is resolved (EPC, 2010, Art 109; Veronese, 2009). This means that a patent revoked in opposition remains valid pending the outcome of the appeal. The Board may uphold the decision, modify the decision, or remand the case to the Opposition Division for further action. In most cases, the Board's decision is final since further appeal of an opposition to the Enlarged Board of Appeal is only possible in very limited circumstances such as fundamental procedural violations or criminal acts (Veronese, 2009). Appeal to a court is impossible. No multinational court exists for that purpose and a direct appeal is not within the jurisdiction of national courts.

Oppositions can take an excessively long time to complete. According to the EPO, the grant procedure takes about three to five years from the application date. The average opposition takes 2.2 years if the patent is revoked and 4 years if the patent is amended. Appeals can add another two years. (Scellato, et al. 2011). The entire process can average between seven to eleven years, although it can last much longer. The European patent application for the famous genetically modified OncoMouse, filed in June of 1985, was initially denied as unpatentable by the EPO. The process of moving through opposition and appeal culminated nineteen years later when the Board remitted the matter to the Opposition Division in July of 2004 with directions to 
enter a modified patent (Harvard/Transgenic animal, 2005). Ultimately, the patent was revoked because the owner didn't pay the fees. Although the average case is not as time consuming, the OncoMouse example illustrates the impact the process can have on the inventor and on society. The longer an opposition takes to reach a conclusion on patentability, the more detrimental the impact on the patent holder and competitors. Uncertainty about the scope of the patent impacts the patent owner's exploitation of the invention. Competitors may not invest if the possibility of their infringing is not clear (Caviggioli, et al., 2012).

\section{B. The Relationship between EPO Oppositions and National Courts}

Once the opposition and appeal have concluded finding a patent invalid, the matter has ended. It will be revoked retroactively in each contracting state in which it was validated. If the process finds the patent is valid entirely or in amended form, validity may only be challenged in each country individually under that country's law. The EPC has harmonized grounds for revocation in contracting states in Article 139 (EPC, 2010). The broad grounds for revocation track those for invalidity in oppositions, including: the subject matter is not patentable, the invention is not sufficiently disclosed, or the subject matter extends beyond the application. National court challenges to patent validity may arise as defenses to infringement suits or in separate actions to declare the patent invalid (Jacobs, 2012). Differences in procedural and substantive law and the time it takes to resolve a case can lead to very different validity outcomes in different countries. And, how a nation deals with revocation proceedings can impact the use of EPO opposition proceedings by its nationals. The majority of European countries handle issues of infringement and validity in the same court (Moss \& Jones, 2008; 
Judge, 2002). A minority, including Germany, bifurcate issues of infringement and validity. German law mandates only the Bunderpatentgericht, the Federal German Patent Court may determine validity. If validity is raised as a defense in a German infringement suit before the Bundegerchitshof (BGH), the Federal Court of Justice, the party raising the defense must file a separate action for invalidity with the Bunderpaentgericht. The BGH has no jurisdiction to declare the patent invalid. The Bunderpatentgericht has no jurisdiction to decide infringement. Only $25 \%$ of parties sued for infringement in BGH cases file separate invalidity actions in only 25\% of all cases (Jacobs, 2012). The BGH may stay the infringement action pending the outcome of the invalidity proceeding, but it is unlikely to do so unless it is obvious that the patent is invalid (Marsnik \& Thomas, 2012). This means that if the BGH decides infringement before the Bunderpatentgericht determines validity, which is often the case, a defendant is put at a commercial disadvantage. Since he has been found to be infringing, he may not be able to sell his products pending the outcome of the invalidation suit. (Jacobs, 2012) This bifurcation feature of the German system may positively impact the number of oppositions filed by Germans. $61.2 \%$ of all European patents opposed have at least one German opponent, a rate nearly six times as high as the next highest opposing country. Furthermore, $72 \%$ of European oppositions in which a German is a party are against other Germans. No other country has such a high fraternal opposition rate (Boff, 2012). The bifurcated German system has an impact.

Parties may not have to wait until the conclusion of an existing EPO opposition to challenge the validity of a European patent in a national court. In many countries, a national revocation proceeding or trial may run parallel with an EPO opposition. In countries in which parallel proceedings are possible, national courts determine whether their cases will be stayed during the pendency of the opposition. U.K. courts typically will not stay court proceedings unless the 
opposition is close to a decision (Boff, 2011). Under German law, a validity action cannot be filed with the Bunderpatentgericht as long as an opposition may still be filed or while opposition proceedings are pending (Patentgesetz, 2009, §81(2)).

A determination on an issue by the Opposition Division or Board does not preclude a party from raising and arguing the same issues in a national revocation case. The EPC contains no estoppel provision (Gupta and Feerst, 2012; Boff, 2011). The probability of winning a suit in a national forum having lost before the Opposition Division and the Board is low. Graham and Harhoff conducted a study of patents surviving European opposition and were later challenged before the German Bunderpatentgericht (2006). They found that opposition hardened the patent rights. National courts defer to EPO decisions since judges endeavor to interpret their national laws in a manner that doesn't contradict the EPC and the decisions of the EPO (Scellato, et al., 2011). Despite this deference, it is possible for a party to successfully convince a national court that a patent granted by the EPO should be revoked, even after it has been validated in opposition. However, the revocation decision of the national court applies only in that country.

\section{Costs of EPO Oppositions and National Revocations}

It costs less to oppose patents in the EPO than individually challenging the patent in each European country in which it has been validated. The filing fees for oppositions and appeals are $€ 705$ (\$915) and $€ 1180$ (1532) respectively. Total average costs of European oppositions range from $\$ 15,000$ to $\$ 50,000$ through decision, but can be more if the case is complex or there are multiple parties opposing the patent. The costs of appeal can approach or surpass the cost of the opposition (Boff, 2011). Although each party typically bears the cost of the opposition, unlike 
the loser pays rule in typical European national litigation, the Opposition Division may order a party to pay all costs for "reasons of equity" (EPC, 2010, Art. 104). The equity provisions apply when "the costs are culpably incurred as a result of irresponsible or even malicious actions" (EPO, 2012, Part D, IX, 1.4.; Graham \& Harhoff, 2002). This rule has been characterized as an anti-troll provision that protects against abuse of the opposition proceeding.

The cost for nullifying or invalidating a patent at the national level varies. No published source exists with this information across jurisdictions. In most European jurisdictions an infringement and revocation action cost between $€ 100,000(\$ 130,000)$ and $€ 200,000(\$ 260,000)$ (Moss \& Jones, 2008). The amount can vary greatly by jurisdiction, particularly since some jurisdictions have more liberal discovery and others may regulate lawyers' fees. Even a relatively straight forward suit in England will cost $£ 500,000(\$ 812,000)$ with more complex cases costing in excess of $£ 1$ million ( $\$ 1.6$ million). Similar amounts can be spent on an appeal.

In most instances the European opposition is a more attractive option than national litigation for reasons of cost, national judicial procedure and for purposes of initially securing a uniform patent across European countries.

\section{Post Grant Review Under the America Invents Act}

The AIA added multiple options within the PTO that allow third parties to challenge the validity of patents post issuance in trial like proceedings. This chapter focuses on post-grant review, the proceeding that most closely resembles European opposition. The new inter partes review, a reworking of the previous inter partes reexamination, has no EPC equivalent. It is a narrower proceeding limited to third-party challenges available only after post-grant review and 
only on novelty and non-obviousness grounds. It is primarily designed to address issues of prior art in patents and printed publications after the post-grant review window has closed. There is also a post grant review for certain business method patents that also has no equivalent under the EPC. Because of its special nature, it is beyond the scope of this chapter.

Congress added the post-grant review mechanism to the American patent system to provide competitors with a faster and less expensive route to testing the validity of newly granted patents of dubious validity (Matal, 2012). The new post issuance proceedings under the AIA are not America's first experiment with third party intervention at the PTO. More than a decade ago, the American Inventors Protection Act of 1999 introduced inter partes reexamination, allowing third parties to initiate an administrative alternative to litigation on grounds of novelty and nonobviousness based on prior art consisting of patent or printed publications (Patent Act of 1952, $\S 303(a))$. The inter partes reexamination was rarely used and is no longer available. According to the most current published data, only 1659 inter partes reexaminations have been filed in total (PTO, Inter Partes Reexamination Filing Data, 2012). It did not fulfill its potential of providing an effective, low cost alternative to litigation. In large part, its estoppel provisions prevented wide use. In a civil action following the inter partes reexamination, the person requesting the reexamination was estopped from asserting the invalidity of any claim found to be valid on any grounds it "raised or could have raised" during the reexamination" (Patent Act of 1952, $\$ 315(c)$ ). The broad consensus among patent experts indicated the estoppel risk to a challenger was too great (Farrell and Merges). Similar, although less restrictive, estoppel provisions in both inter partes review, which replaces inter partes reexamination, and post-grant review could have a similar impact. 


\section{A. Post Grant Review}

The AIA post-grant review resembles European opposition in a number of key features and differs in significant ways. Post-grant review and oppositions are similar in terms of who may file, the time frame for filing, and the relationship of validity grounds in the administrative trial to those used in civil cases. Under $\$ 321$ of the AIA, any person who is not the owner of the patent may file a petition to institute a post-grant review no later than nine months after the date of the patent grant or issuance of a reissue patent (Leahy-Smith America Invents Act, 2011, §321). Similar to the European opposition, patentability may be challenged on broad grounds. Under the AIA, these include novelty, non-obviousness, abandonment, failure to comply with requirements for the specification. (Leahy-Smith America Invents Act, 2011, § 321). The Director reviews the petition and may not authorize the review unless the petition presents information, which if not rebutted, demonstrates "that it is more likely than not at least 1 of the claims challenged in the petition is unpatentable" or that is raises "novel or unsettled legal question" important to other patents or applications. (Leahy-Smith America Invents Act, 2011, § 324). This threshold essentially requires the petitioner to present a prima facia case. Its practical effect requires petitioners to closely tie its challenges to particular arguments against particular claims (Matal, 2012). Thus, the AIA incorporates a higher initial threshold showing than is required in the EPO. The grounds for determining a European opposition inadmissible are primarily based on technical non-compliance with filing rules, not a threshold showing of invalidity. The post-grant review will be heard by a newly created Patent Trial and Appeal Board (PTAB) sitting in panels of three administrative judges having both legal and technical competence. The composition of the PTAB differs from the typical panel of three technical experts on the Opposition Division panels. Their functions differ, as well. Opposition Division 
panels function in a quasi-judicial capacity while the PTAB's function is judicial. A critical difference between the European opposition and the post-grant review is the duration of the proceeding. The AIA mandates that the PTAB must issue its final determination one year from the PTO's notice of proceeding, although the decision may be delayed for up to six months for good cause (Leahy-Smith America Invents Act, 2011,§326). The EPC has no such time limit.

As with European oppositions, there are four possible outcomes of the post-grant review. The PTAB must issue a written decision and: (1) publish a new certificate cancelling any claim determined to be unpatentable, (2) publish a certificate confirming any claim determined to be patentable, (3) publish a certificate incorporating new or amended claims determined to be patentable, or (4) terminate the post-grant review (Leahy-Smith America Invents Act, 2011, $\S 328(b))$. Section 327 mandates that the post-grant review be terminated with respect to any petitioner upon a joint request by the petitioner and patent owner upon submission of a settlement agreement, unless the post-grant review has been decided prior to the filing of the termination (Leahy-Smith America Invents Act, 2011). However, the PTAB retains discretion to terminate the review or continue reviewing a challenged patent even if no petitioner remains in the post-grant review (Leahy-Smith America Invents Act, 2011, §327(a); PTO, Rules of Practice, $2012, \S 42.74(a))$. The PTO takes the view that the issue of patentability is not subject to settlement and will consider the facts of each case in determining whether to proceed to written decision. The final rules provide that the PTAB may independently determine any question of patentability. (PTO, Rules of Practice, 2012, §42.74(a)). This discretion to continue deciding patentability without the parties may prove to be as powerful a deterrent against settlement as Rule 84(2) of the EPO's Implementing Regulations. However, post-grant review petitioners have incentives to settle under Section 327 that do not exist in the European opposition. If a 
petitioner settles under Section 327 and the post-grant review is terminated and no estoppel attaches to the petitioner, its real party in interest or privy. Because estoppel is not an issue in EPO oppositions, the same incentive to settle does not exist. For this reason, a petitioner under the AIA may prefer to settle a post-grant review, rather than proceed to a final written determination. Either party may appeal the PTAB judgment directly to the Court of Appeals for the Federal Circuit (CAFC) (Leahy-Smith America Invents Act, 2011, §141).

\section{B. Relationship of Post Grant Review and Other Proceedings}

The AIA includes rules governing the relationship between post-grant review and other proceedings. The estoppel provisions are among the more controversial due to their broad scope and how early they attach.

Parties who have a final written decision from the PTAB may not assert in a subsequent PTO proceeding, such as an inter partes review, or in a civil action, whether it be Federal Court or an action before the International Trade Commission, any grounds for invalidity that the petitioner "raised or reasonably could have raised during that post-grant review" (Leahy-Smith America Invents Act, 2011, §325(e)). The "reasonably could have raised" estoppel provision is troublesome. The language was meant to soften the estoppel provisions of inter partes reexamination, which precluded a party raising an issue it "could have raised" in reexamination in subsequent litigation. Matal, in his legislative history of the AIA, quotes Senator Kyle's explanation for adding the modifier "reasonably" was meant to "ensure that the could-haveraised estoppel extends only to that prior art which a skilled searched conducting a diligent search reasonably could have been expected to discover" (2012). The "reasonably could have 
raised" standard was added to the new inter partes review, replacing inter partes reexamination (Leahy-Smith America Invents Act, 2011, § 314(e)). It was meant to prevent duplicative administrative and judicial proceedings. The standard was never meant to apply across the board to all proceedings subsequent to post-grant review. Earlier versions of patent reform bills limited post-grant review estoppel in subsequent civil cases only to issues actually raised and decided. Business and patent law professional associations supported the limitation in subsequent litigation, fearing that if the estoppel effects of post-grant review were too harsh, it would not be used. In all versions of the bill, except the final version, the "reasonably could have raised standard" for post-grant review only applied to subsequent administrative proceedings such as inter partes review. However, in the final version of the bill the "reasonably could have raised" standard applied to civil litigation, as well. Since nothing in the record acknowledged this change, it appears to be an error made in the final version (Matal, 2012).

Post-grant review estoppel relating to civil actions attaches early. Section 325(e)(2) provides that a post grant review that results in a final written decision precludes a petitioner, real party in interest or privy from raises invalidity grounds raised or reasonably could have raised. This language indicates estoppel attaches upon the written decision, not after the appeals have been exhausted. Given that post-grant review determinations must be made within twelve or eighteen months, estoppel may have a fairly imminent impact. It is unclear how the CAFC will interpret the estoppel language. In a recent case, the CFAC held that the estoppel effect of an inter partes reexamination required all appeals be exhausted before estoppel attached (Bettcher v. Bunzl, 2011), which could take six years. (McKeown, 2011). It is possible the CAFC could interpret the post-grant review language in a similar manner. 
The AIA contains rules governing the relationship between post-grant reviews and civil actions. A post-grant review may not be instituted if a petitioner has previously filed a declaratory judgment for invalidity. However, that party may file a petition for a post-grant review challenging the validity of one or more claims any time after filing a declaratory judgment action. Filing the post-grant review triggers an automatic stay of the court action. The stay may not be lifted until the patent owner moves the court to lift the stay, the patent owner files an action or counterclaim for infringement, or the post-grant review petitioner moves the court to dismiss the claim (Leahy-Smith America Invents Act, 2011, § 325(a)). Given the postgrant review estoppel provisions, the PTAB will make the final determination on patentability of a particular claim. Post-grant review proceedings may only coexist with litigation if the patent owner has filed a claim or counterclaim for infringement. If the patent owner files a preliminary injunction action alleging infringement within three months of the patent grant, the court may not stay the action on the grounds that the petitioner has filed a post grant review (Leahy-Smith America Invents Act, 2011, $\S 325(\mathrm{~b}))$. Therefore, if a post-grant review is progressing parallel to a court action under circumstance allow by the AIA, a ruling by the PTAB on patentability will estop the court from determining validity. A ruling by the trial court does not have the same effect on proceedings before the PTAB.

\section{Costs of Post-Grant Review and Other Procedural Issues}

A key reason for incorporating third-party post grant proceedings in the America Invents Act was to provide a more cost effective alternative to litigation. On August 14, 2012, the PTO published its final rules, including fees and estimated the costs of a post-grant review. The 
filing fee, which must be submitted with the post-grant review petition, depends upon the number of claims (PTO, Changes to Implement, 2012, § 42.203). The basic fee of $\$ 35,800$ applies to petitions challenging up to twenty claims with $\$ 800$ added for each additional claim (PTO, Rules of Practice, 2012, § 42,15(b)). Therefore, if sixty claims are contested, the filing fee totals $\$ 67,800$. Although these fees are lower than the escalating fees originally proposed in February 2012, they are exponentially higher than the $€ 705$ (\$915) fixed filing fee for an EPO opposition. Several comments made during rulemaking suggested setting a low filing fee with no additional fees for additional claims (PTO, Rules of Practice, 2012). The fees remain substantial because AIA does not provide for setting post-grant review fees at below the cost to the PTO (Leahy-Smith America Invents Act, 2011, §321(a).

Attorney fees for a post-grant review dwarf the filing fee. The PTO estimated the cost of a post-grant review based on the AIPLA mean private firm attorney fee of \$371per hour and the number of hours to prepare for various stages in the proceedings (PTO, Rules of Practice). Based on these figures, the PTO calculates the attorney fees to prepare a petition at $\$ 61,333$. The patent holder is allowed to make a preliminary response prior to the PTO threshold determination, estimated to cost $\$ 34.000$. Once the PTO has made a determination that the petition meets the statutory requirements, the patent owner may reply and a third party may make a statement, estimated at $\$ 29,000$ each. The PTO projects the average post-grant review will include 8 motions, oppositions and replies at an average cost of $\$ 44,200$ each, including the cost of experts and preparing briefs (PTO, Rules of Practice, 2012). Until 2017, an Information Technology fee of $\$ 1750$ for up to twenty claims and $\$ 75$ for each additional claim will also be assessed. Based on these estimates, a petitioner will spend nearly half a million dollars for a petition contesting twenty or fewer claims. The patent owner faces similar expenditures, less the 
filing fee, but may have to face a subsequent inter partes review or potential litigation by a person not the petitioner or one of its real parties in interest or privies.

The proposed rules set a maximum of eighty pages for post-grant review petitions in 14point type or larger and double spaced regardless of the number of claims challenged or the complexity of issues presented. The petition must identify all real parties in interest and certify that the petitioner is not estopped from proceeding. It must identify all claims challenged, the grounds upon which the challenge to each claim is based, provide claim construction and show how the construed claim is unpatentable based on the grounds alleged. The petition may include a statement of material facts. The table of contents, table of authorities, and certificate of service and appendix of exhibits are not included in the page count. The page limit may be waived by motion, but the petitioner must show that doing so would be in the interests of justice and must append a copy of the proposed petition exceeding the page limit (PTO, Rules of Practice, $2012 \S$ 42.24). Given the growth in the number of patent claims and the complexities of technology, the page limits may not be sufficient to fully address the post-grant review threshold requirement of "more likely than not at least 1 of the claims challenged in the petition is unpatentable." In order to meet the page limit restrictions, it may be necessary for petitioners to file multiple petitions focusing on different claims, and pay the minimum filing fee each time. This will increase costs to petitioners and decrease efficiency.

IV. Post Grant Review Will Not Improve the Quality of Patents

It is unlikely the AIA post-grant review system will accomplish the social welfare benefits of improving patent quality and providing an efficient alternative to litigation. This 
section delimits some of the flaws in post-grant review that will hamper its effectiveness. No post grant system for opposing patents will be successful unless it is used. Factors such as cost, page limits of the petitions and the harsh estoppel provisions may make it an unattractive alternative to third parties who might otherwise benefit from a finding of invalidity.

\section{A. Factors Limiting the Effectiveness of Post-Grant Review}

Only patents issued under the new AIA first-inventor-to-file (FITF) system are eligible for post-grant review. Given the FITF doesn't go into effect March 16, 2013 and petitioners will likely take the nine months allowed to prepare their petitions, it will be some time until the effectiveness of post-grant review is known. However, it is not likely to be effective. The United States does not have a history and tradition of trial like inter partes post issuance review. Given proper incentives, U.S.-based third parties would use the systems, but the AIA does not include the proper incentives. Americans are the second most likely nationality to oppose European patents after the Germans, accounting for approximately $11.5 \%$ of European oppositions (Boff, 2012). Many of the incentives for utilizing European oppositions are the same for Americans as for others using the system. European oppositions are relatively inexpensive and preferable to national revocation proceedings, particularly in Germany. Despite the efficiencies of the European system, only about 5\% of all patents are opposed. Based on statistics for granted utility patents in 2011, if the PTO were faced with post-grant review filings at the EPO rate, it would be flooded with over 25,000 filings. The AIA empowers the PTO to limit the number of inter partes reviews and post-grant reviews during the AIA's first four years. The PTO does not expect to limit the number of petitions granted. However, if the PTO rejects a 
substantial number of inter partes review petitions on these grounds, after the petitioner has incurred the expense of filing, whether a third party chooses the non-litigation route may be impacted. Too many rejections may undermine confidence during the early years of the system when a tradition of using post-issuance reviews should be built.

When post issuance administrative review is too expensive, the incentives for potential challengers to use it diminish. Graham and Harhoff calculate that when the cost of a post grant review reaches $\$ 500,000$, the welfare benefits are eroded (2006). As demonstrated, the cost of pursuing a post-grant review can approach that amount, even when twenty or fewer claims are contested. The costs escalate when there are a large number of claims involved or when multiple post-grant reviews must be filed to cover a substantial number of challenges within the administrative page limit requirements. Fewer competitors will likely use a very expensive system, which will negatively impact the usefulness of the system to catch and correct weak or invalid patents.

The cost may particularly deter individuals and small to medium sized companies. Just paying the filing fee and filing the petition for the post-grant review is projected to cost more than the average cost of the entire European opposition. The difference between a $€ 705$ filing fee (approximately $\$ 915$ ) and one that begins at $\$ 35,800$ and escalates in increments of $\$ 800$ per claim is immense. The EPO's lower fee encourages use of the system and shields independent inventors and small and medium sized enterprises from strategic abuse of the system (Hall and Harhoff, 2004). The AIA contains no such protection for small to medium sized entities. Moreover, it is unlikely to be used by smaller entities subject to infringement litigation. Under litigation threat by non-practicing entities, often described as trolls, most companies settle to avoid expensive litigation and the potential of a permanent injunction that could destroy their 
business (Thomas, 2006). Trolling activities are unlikely to decrease even though post-grant opposition in the U.S. has been touted as a way to limit them (Mayergoyz, 2009). If a nonpracticing patentee sues, post-grant review is a viable alternative only if the lawsuit is filed early in patent's life. If sued after the nine month post-grant review window, the small entity may resort to an inter partes review on narrower grounds and based only on published prior art. The inter partes review is subject to some of the same negative features as the post-grant review including estoppel and high and escalating fees, although set thirty-three percent lower than those for post-grant review due to more limited grounds. McKeown has pointed out, the economics of the "troll game" make the proposed AIA fee structure an unworkable alternative (2012(a)). Non-practicing entities will typically dismiss a party from a law suit for a licensing fee of $\$ 100,000$ to $\$ 300,000$ (McKeown, 2012(a)). Given the cost of a post-grant review, it may be more economically feasible and less risky for a small entity to settle the lawsuit without resorting to post-grant or inter partes review.

The estoppel provisions may serve as the most effective barrier to the success of American post-grant review. These provisions are likely to plague post-grant review in the same way estoppel precluded inter partes reexamination. The broad consensus among patent experts and the PTO recognized that estoppel was the most frequently identified issue for deterring third parties from filing requests for inter partes reexamination (Carlson \& Migliorini, 2006; Farrell and Merges, 2004). A third party could file a request for inter partes reexamination at any time ((Patent Act of 1952, § 311(a)). This provided ample time for those willing to brave the estoppel provisions to determine which novelty or non-obviousness attacks had the most merit and to brief them without page limit restrictions. In contrast, a petitioner for post-grant review has only nine months to determine whether a post-grant review is feasible and present all the grounds it 
wishes to preserve against particular claims in a petition limited to eighty pages. The nine month post-grant review window may prove particularly burdensome in industries such as pharmaceuticals or medical devices requiring clinical trials and for those selling products with thousands of component parts containing patents, such as the computer or cell phone industry (Carrier, 2011). It may not be possible to discover a potentially invalid patent and to file a review on all possible grounds within nine months. Given the time frame, it may not be desirable. Estoppel in a post-grant review attaches upon a written decision of the PTAB, twelve to eighteen months from the date the proceeding was initiated because of the statutory requirement it must be completed during that time period. The twelve months mandated under the AIA to reach a decision is about one third the average 36.1 month pendency of an inter partes reexamination (PTO, Inter Partes Reexamination Filing Data, 2012). Challengers may not trust the PTAB to correctly rule in a post-grant review given how quickly the determination must be made. Even though the outcome of the post-grant review may be appealed to the CAFC, it is as yet unclear whether estoppel will attach upon a PTAB judgment or after the appeal. Furthermore, the challenger forever loses its opportunity to have the issue fully adjudicated on different later discovered grounds or evidence, if those grounds were raised or reasonably could have been raised during the post-grant review.

Post-grant review's broad "reasonably could have raised" standard was never meant to apply to civil litigation. Given the broadness of the estoppel provision, how quickly a party must determine whether to oppose a grated patent and the speed at which the PTAB must reach its final conclusion, a third party is unlikely to use risk a post-grant review. It must be remembered that the EPC contains no estoppel provisions preventing further litigation on the same issues decided by the EPO. Although national courts may defer to EPO decisions, the lack of estoppel 
provides a check on the accuracy of the European opposition system by national courts. No evidence exists that this practice has exposed patentees to multiple challenges. More importantly, it has allowed the national courts to serve the interests of the public by subjecting patents to an additional level of scrutiny. Limiting estoppel in litigation circumstances in the United States to grounds actually raised in a post-grant review would make the procedure more palatable to potential users. It would also better serve society in offering additional avenues to test patents.

A post grant review system allowing for easy settlement erodes the very purpose of a system designed to improve patents. Prior to joining the EPC, the U.K. patent law included both pre-grant and post-grant opposition procedures with no barriers to settlement. $75 \%$ of all U.K. oppositions ended in settlement, which did not preclude U.K. courts from later revoking the opposed patents (McKie, 1974). As McKie observed forty years ago, competitors oppose patents to protect their interests, not the public's interest. If a third party can reach the result he wishes through a negotiated licenses, that will be the likely path, rather than an expensive opposition (1974). The AIA mandates terminating the proceeding as to any petitioner upon joint request of the petitioner and the patent owner unless the PTAB has decided on the merits. Such a termination means that no estoppel attaches to that petitioner, its real party in interest or its privy. Although the AIA grants the PTAB discretionary power to terminate the review or proceed to a final written decision, the contours of that discretion are yet to be tested. The PTO has indicated its decision to terminate the review or to proceed to a final written decision depends on the particular facts (PTO, Rules of Practice, 2012). How the PTAB approaches those facts and makes its determination will determine whether the AIA settlement provisions open the system to misuse. If too lenient in continuing to final written decision without the petitioners, a competitor could file a post-grant review to force a patentee into negotiating a license, or risk 
invalidation or narrowing of claims. Settling the post-grant review in exchange for the license may make it a more commercially viable option. Liberally allowing for settlement without the threat of a final PTO determination on patentability would mean neither the parties nor society at large would ever know whether the challenged patent truly was valid. An opposition system discouraging settlement more effectively supports the goal of improving the quality of patents. The EPO's procedures allowing the Opposition Division to continue after the parties have withdrawn have acted as a "powerful deterrent" to settlement (Hall \& Harhoff, 2004). Unless the AIA systemic barriers to hinder settlements are enforced it is unlikely the public will benefit from a post-grant review. Therefore, the PTAB should exercise its discretion to determine patentability whenever possible.

\section{B. Post Grant Review in National Systems}

Administrative post-grant review may be more appropriate and effective in multinational patent systems. Few countries maintain post-grant time limited administrative review systems. Only thirty percent of EPC contracting states have post grant oppositions as part of their national systems (European Patent Academy, 2010). It is not surprising that Germany, whose nationals file the majority of European oppositions, includes an opposition for patents filed nationally. German law requires filing national oppositions within three months of the grant, making its general usefulness questionable. Before acceding to the EPC, the U.K. had two oppositions systems, one that allowed third party intervention prior to issuance and the other allowing for opposition within one year of the grant. The system was used in only about $1 \%$ of cases and was often used for delaying tactics or to harass patentees (McKie, 1974). Neither form of national 
opposition made it into the UK Patents Act 1977, enacted to transpose the EPC requirements into U.K. law (1977).

More recently, Japan abolished its time limited post grant opposition system in favor of a single, non-time limited patent invalidation trial within the Japanese Patent Office (Carlson and Migliorina, 2006). In 1996, Japan implemented a post grant opposition system to replace a pregrant opposition system, which had been misused and delayed the grant of patents. In 2003, only seven years after introducing the system, Japan abolished its post-grant oppositions. It found a dual system of opposition and a separate trial system for invalidation burdened patentees who were subjected to repeated attacks against the same patent (Sun, 2004; Tessensohn and Yamamoto, 2003). The current system provides for an invalidation trial within the Japanese Patent Office as the sole mechanism to invalidate patents issued or filed after 2004. The parties may appeal through the court system. Nothing in the law estops a challenger from filing subsequent requests for a new invalidity trial based on different grounds (Carlson \& Migliorina, 2006).

Evidence from these examples indicates that when post grant oppositions coexist with other avenues for invalidation on a national level, opportunities to misuse the system occur. The America Invents Act provides what has been characterized as an "arsenal" of proceedings to weed out low-quality patents (Tran, 2012). Besides litigation and post-grant review, procedures include supplemental examination, ex parte reexamination, inter parties review, and a separate post grant review for business methods relating to financial services and products. These routes to reexamination and reconsideration overlap, making the U.S. system much more complex than other national or multinational systems by the sheer number of avenues available for challenging patents in addition to litigation. These multiple avenues for invalidation raises the potential of 
undue harassment of patentees and duplicates patent office resources in administration of parallel systems (Carlson and Migliorina, 2006). Some of the abuses experienced in other nations' systems may be ameliorated in the U.S. system by the high cost of the procedure and the postgrant review estoppel provisions. However, those are two of the very provisions that may ensure the procedure is not used.

The landscape is different in the multinational European system. Without a post grant oppositions and appeals procedure in the EPO, invalidation of patents in Europe would be piecemeal and lead to differing results in different nations. A central procedure for oppositions at the EPO lowers costs and enhances predictability, since the invalidation or narrowing of the patent has immediate effect in all EPC national jurisdictions. The structure of national infringement and invalidation proceedings makes the European opposition more appealing to some nationals than others. Germans have a long history of using their national opposition system prior to joining the EPC (McKie, 1974). Oppositions are often used as a way to narrow patents. Structural reasons exist for a German propensity to use oppositions as a primary route to challenging the validity of patents. Within a national system in which infringement and invalidation are bifurcated into two separate courts - courts that can and do reach decisions on infringement and validity at different times - European opposition proves to be a less risky route to invalidation.

\section{Conclusion}

Post-grant review under The America Invents Act will not improve the quality of patents in the U.S. Although it has been characterized as the most powerful tool in an arsenal of new post-grant administrative proceedings (Tran, 2012), it is unlikely to be a useful tool without substantial changes to the law. Following the example of the European opposition, the fee 
structure must be modified to make the cost of filing and perusing post-grant review a feasible option. This is particularly important in order to shield independent inventors and small and medium sized enterprises from strategic misuse of the system. This cannot be accomplished without modification of $\S 321$ (a) requiring the PTO to consider the aggregate costs of the postgrant review in setting fees. Estoppel is not a feature of European opposition law. No evidence suggests that a lack of estoppel has led to strategic abuse by parties between the multinational and national systems. Furthermore, it serves the public interest of assuring patents administered at the national level are valid. Estoppel poses similar and different issue in the U.S. national system in which a party may bring other administrative proceedings or civil actions. Patentees should be protected from harassment by third parties misusing the system. However, the public's interest in valid patents should outweigh that interest given the purpose of the patent system to advance the useful arts. Preventing the rehearing of issues actually decided by the PTAB in post-grant reviews could more equitably accomplish this goal. Legislative history indicates that Congress never intended "reasonably could have raised" estoppel to prevent subsequent litigation on patent validity. As predicted, this provision will serve as a significant obstacle to post-grant review's usefulness. At a minimum, it is imperative Congress act to correct this mistake.

Uncertainty in the AIA settlement and termination provisions has the potential to undermine the purpose of post-grant review to insure the quality of patents. Given the PTO's discretion to continue to final written decision without petitioners indicates the AIA may contain the same powerful deterrent to settlement that exists in the EPC. Without this safeguard, if a substantial number of post-grant reviews terminate in settlement without a PTO decision on patentability, the public's interest in the quality of patents would be compromised. 
*Associate Professor of Business Law at the Opus College of Business, University of St. Thomas. Copyright 2012, Susan J. Marsnik. The author wishes to extend her thanks to Daniel R. Cahoy, Smeal College of Business, Penn State University, Lynda J. Oswald, Ross School of Business, University of Michigan for organizing the May 2012 colloquium “The Changing Face of American Patent Law and Its Impact on Business Strategy." The author is grateful for rigorous comments and suggestions from all the participants. The author extends special thanks to her research assistant, Ryan F. Brackin, University of St. Thomas Law School class of 2013, for his indefatigable assistance on this and other research project.

1 The EPC is not a convention of the European Union (EU). Despite efforts to join the EPC, the EU is not a party, although each of the 27 EU Member States are among the 40 European nations that are Contracting States to the EPC.

2 A second exception exists. EPC 2000 introduced a new proceeding allowing patent owner to limit claims in a granted patent under Article 105(a). Under this procedure, a patent can be narrowed or revoked and the result will apply retroactively in each of the countries in which the patent has been validated. (Rudge, 2012). 
References

Allison, J. R., Lemley, M. A., \& Walker, J. (2009). Extreme value or trolls on top? The characteristics of the most-litigated patents. University of Pennsylvania Law Review, 158, 1-37.

Allison, J. R., Lemley, M. A., Moore, K. A., \& Trunkey, R. D. (2004). Valuable patents. Georgetown Law Journal, 92, 435-479.

American Intellectual Property Law Association (AIPLA) (2011). AIPLA report of the economic survey 2011. Arlington, VA.

Bettcher v. Bunzl, 661 F.3d 629 (2011).

Boff, J. (2011). Challenging European patents and applications, AIPLA 2011 spring meeting, AIPLA IP practice in Europe committee, available at http://www.docstoc.com/docs/98459516/Challenging-European-Patents-and-Applications-in-theEPO.

Boff, J. (2012). Bifurcation - good for patent attorneys, bad for industry? CIPA Journal, 41(7), 386-388.

Carlson, D. L., \& Migliorini, R. A. (2006). Patent reform at the crossroads: Experience in the far east with oppositions suggests an alternative approach for the United States. North Carolina Journal of Law \& Technology, 7, 261-319. 
Carrier, M. A. (2011). Post-grant opposition: A proposal and a comparison to the America invents act. University of California Davis Law Review, 45, 103.

Case G 9/93. (1994). Official Journal of the European Patent Office, 12, 891. (Enlarged Board of Appeal, July 6, 1994).

Caviggioli, F., Scellato, G., \& Ughetto, E. (2012). Understanding patent quality: Evidence from patent opposition cases at the European patent office. Working paper presented at the 6th annual conference of the European Policy for Intellectual Property Association. Brussels, BE.

Convention on the Grant of European Patents (EPC), Oct. 5, 1973, as revised Nov. 29, 2000. (2010). The European Patent Convention (14 ${ }^{\text {th }}$ ed.), Munich, Germany: European Patent Office.

European Patent Academy. (2010). Patent litigation in Europe: An overview of the national patent litigation systems in Europe (2nd ed.). European Patent Office.

European Patent Office (EPO) (2012, June 12). Guidelines for examination in the European patent office, available at http://www.epo.org/law-practice/legal-texts/guidelines.html.

European Patent Office (EPO) (2010, October 23). Implementing regulations to the convention on the grant of European patents, Oct. 5, 1973, available at http://www.epo.org/lawpractice/legal-texts/html/epc/2010/e/ma2.html. 
Farrell, J., \& Merges, R. P. (2004). Incentives to challenge and defend patents: Why litigation won't reliably fix patent office errors and why administrative patent review might help. Berkley Technology Law Journal, 19, 943.

Federal Trade Commission. (2003). To promote innovation: The proper balance of competition and patent law and policy. Washington, D.C.: The Federal Trade Commission.

Graham, S., Hall, B. H., Harhoff, D., \& Mowery, D. C. (2002). Post-issue patent "quality control:" A comparative study of U.S. patent re-examinations and European patent oppositions. (Working Paper No. 8807). Cambridge, MA: National Bureau of Economic Research \& Competition Policy Center, University of California, Berkeley.

Graham, S. \& Harhoff , D. (2006). Can post-grant review improve patent system design? A twin study of U.S. and European patents." (Discussion Paper No. 5680). Washington, D.C.: Center for Economic Policy Research.

Gupta, P. R., \& Feerst, A. (2012). The U.S. patent system after the Leahy-Smith America invents act. European Intellectual Property Review, 34(1), 60.

Hall, B. H., \& Harhoff, D. (2004). Post-grant reviews in the U.S. patent system - design choices and expected impact. Berkeley Technology Law Journal, 19, 989. 
Harhoff, D., \& Reitzig, M. (2004). Determinants of opposition against EPO patent grants -- the case of biotechnology and pharmaceuticals. International Journal of Industrial Organization, 22, 443-480.

Harvard/Transgenic animal (T315/03) (2005) European Patent Office Reports, 31 (Technical Board of Appeal, Jul. 6, 2004).

Hoyng, W. A. (2006). The European patent convention. In W. A. Hoyng, \& F. W. E. Eijsvogels (Eds.), Global patent litigation: Strategy and practice. (EPC 1 - EPC 38) London, UK: Kluwer Law International.

Jacob, R. (2012). To bifurcate or not to bifurcate: That is the question. CIPA Journal, 41(6), 328331.

Judge, I. (2002). Developments in the Harmonisation of European Patent Law and Litigation. In H. Hansen (Ed.), International Intellectual Property Law and Policy 7 (28-1 - 28-5). Huntington, NY: Juris Publishing, Inc.

Leahy-Smith America Invents Act. (2011). Pub. L. No. 112-29, 125 Stat. 284. 
Marsnik, S. J., \& Thomas, R. E. (2011). Drawing a line in the patent subject-matter sands: Does Europe prove a solution to the software and business method patent problem? Boston College International and Comparative Law Review, 34(2), 227-327.

Matal, J. (2012). A guide to the legislative history of the America invents act: Part II of II. The Federal Circuit Bar Journal, 21(4), 539-653.

Mayergoyz, A. (2009). Lessons from Europe on how to tame U.S. patent trolls. Cornell International Law Journal, 42, 242.

McKeown, S. A. (2011, September 29). New inter partes review grounds to stay most patent litigation? Patents Post Grant Blog, available at http://www.patentspostgrant.com/lang/en/2011/09/new-inter-partes-review.

McKeown, S. A. (2012(a), February 22). Post grant fee structure a boon for patent trolls? Modern patent troll business model insulated from new post grant challenges. Patents Post Grant Blog, available at http://www.patentspostgrant.com/lang/en/2012/02/proposed-PTO-post-grantfee-structure-a-boon-for-patent-trolls.

McKie, J. \& Edward F. (1974). Proposal for an American patent opposition system in the light of the history of foreign systems. Journal of the Patent Office Society, 56, 94-102. 
Merrill S. A., Levin R. C. and Myers M. B. (Eds.). (2004). A patent system for the 21st century. Washington, D.C.: The National Academies Press.

Moss, G., \& Jones, M. (2008, June 1). Litigating patents in Europe: Navigating the minefield. BNA World Intellectual Property Report, 22(6), D20.

Patent Act of 1952. (1952). 35 U.S.C. $\S \S 1-376$ (as amended).

Patents Act 1977. (1977).U.K..

Patentgesetz (zuletzt geändert durch Gasetz vom 31. Juli 2009) (2009); Germany, Patent Law (as amended by the Law of July 31, 2009), available in English translation at http://www.wipo.int/wipolex/en/details.jsp?id=6128.

Revised European Patent Convention and Implementing Regulation, Nov. 29, 2000. (2003). Official Journal of the European Patent Office, 1.

Rudge, A. (2012). Guide to European patents. Eagan, MN: Thompson Reuters.

Scellato, G., Calderini, M., Caviggioli, F., Franzoni, C., Ughetto, E., Kica, E. \& Rodriguez, V. (2011). Study on the quality of the patent system in Europe, DG MARKT, tender MARKT/2009/11/D, available at http://ec.europa.eu/internal_market/indprop/docs/patent/patqual02032011_en.pdf. 
Sun, H. (2004). Post-grant patent invalidation in china and the United States, Europe, and Japan: A comparative study. Fordham Intellectual Property, Media \& Entertainment Law Journal, 273331.

Tessensohn, J. \& Yamamoto, S. (2003). Japan: patents - new invalidity appeal system. European Intellectual Property Review, 10, 154 - 55.

Thambisetty, S. (2007). Patents as credence goods. Oxford Journal of Legal Studies, 27(4), 707740.

Thomas, R. E. (2006). Vanquishing copyright pirates and patent trolls: The divergent evolution of copyright and patent laws. American Business Law Journal, 42, 689-739.

Tran, S. (2012). Patent powers. Harvard Journal of Law \& Technology, 25(2), 1-67.

United States Patent and Trademark Office (PTO) (2011). FY 2011 PTO Performance and Accountability Report, available at http://www.PTO.gov/about/stratplan/ar/2011/index.jsp.

United States Patent and Trademark Office (PTO) (2011). Summary of total pending patent applications, available at http://www.PTO.gov/web/offices/ac/ido/oeip/taf/us_stat.pdf. 
United States Patent and Trademark Office (PTO) (2012). U.S. patent statistics report, available at http://www.PTO.gov/web/offices/ac/ido/oeip/taf/us_stat.pdf.

United States Patent and Trademark Office (PTO) (2012, August 14). Rules of practice for trials before the patent trial and appeal board and judicial review of patent trial and appeal board decisions; Final rule. Federal Register, 77(157), 48611 - 48678.

United States Patent and Trademark Office (PTO) (2012, August 14) Changes to implement inter partes review proceedings, pos-grant review proceedings, and transitional program for covered business method patents, Final rule, 77(157), 48680 - 48732.

United States Patent and Trademark Office (PTO) (June 30, 2012). Inter partes reexamination filing data, available at http://www.PTO.gov/patents/stats//IP_quarterly_report_June_30_2012.pdf.

Veronese, A. (2009). Appeal procedure before the European patent office. In T. Takenaka (Ed.), Patent law and theory: A handbook of contemporary research (pp. 224-245). Northampton, MA: Edwin Elgar. 